\title{
New Laboratories of the Mond Nickel Co., Ltd.
}

$\mathrm{A}^{\mathrm{T}}$

T a reception which preceded the inspection on October 21 of the new Research and Development Department Laboratory erected by the Mond Nickel Co., Ltd., in Wiggin Street, Birmingham, Lord Weir referred to the great extension that has taken place in the use of nickel and its alloys during the last decade. Before 1914, most of the nickel produced in the world was utilized for armament purposes. As a result of the research and development work that has been carried out since that time, both by the International Nickel Co. and its associates, and by nickel users throughout the world, the metal now enters into a wide variety of alloys and is employed to an increasing extent in nearly every industry. In 1922, the world consumption of the metal was only eight thousand six hundred tons, but this rose to seventy-five thousand tons last year, most of it for uses unconnected with war.

The new laboratories, which are magnificently housed, are fit to take their place among the more important organizations of their kind in the world. The structure is of reinforced concrete, and consists of a basement and three floors on a site $186 \mathrm{ft} . \times 43 \mathrm{ft}$. The building is faced with red brick, and a feature of the front elevation is a curved window extending the full height of the building and lighting the main staircase in the centre of the block. It is a pleasing example of modern architecture.

The opportunity has been taken to display the decorative qualities of some of the Company's products, and nickel alloy metal work is extensively used ; the nickel-silver balustrade to the main staircase is particularly effective.

A notable feature of the laboratory is that it is heated and ventilated by the introduction of fresh warm clean and filtered air from a modern airconditioning plant. This not only avoids the inconvenience of radiators in the laboratory, but also keeps the building free from dust. The automatic control of temperature and humidity thus obtained, as well as the freedom from dust, has definite scientific advantages, particularly in the corrosion laboratory, for the building is situated in the heart of industrial Birmingham where the atmosphere is at times very impure.

Service supplies of gas, water, electricity, etc., are led from the basement through enclosed longitudinal ducts and are distributed to the laboratories through channels in the walls and floors which are enclosed by flush-fitting panels. The benches are mainly tilecovered, and drainage channels are enclosed and hidden under the floor. The walls are finished in cream coloured enamel and, being provided with big windows, make the rooms very light. The absence of pipes and fittings on the walls gives a general air of tidiness, which is further enhanced by the use of nickel alloy sink and other fittings. The general effect is rather that of a modern luxury bathroom than of a typical scientific laboratory.

A portion of the building is deyoted to a large semi-technical laboratory, in which new processes can be studied on a larger scale, preliminary to their transfer to the works.

The general equipment of the laboratories is excellent, and the apparatus available for physical metallurgy is particularly to be commended. The wide variety of alloys of which nickel forms a component renders necessary a particularly wide range of testing appliances, and, except for an $\mathrm{X}$-ray spectrometer, nothing of importance appears to have been omitted.

The laboratory is elearly designed principally for development work rather than pure scientific research; that is, it is intended to supply information, mainly obtained by known testing methods, to users of nickel alloys. For this purpose it is excellent, and it is doubtful if any better laboratory of the kind exists in Great Britain. There is, however, a certain rigidity about the lay-out of the building itself and of the apparatus which is perhaps not quite so desirable in a laboratory devoted to scientific research; but it is, perhaps, ungracious to criticize where there is so much to praise.

\section{Development of the Scottish Highlands}

$\mathrm{T}$ HE drastic depopulation of the Highlands, its causes and the possibilities of development form the subject of a broadsheet on the "State of the Highlands" which has recently been published by Political and Economic Planning. In 1931 the population of the Highland counties, which represent nearly 19 per cent of the area of Great Britain, was 356,615, or less than 1 per cent of Great Britain's population and 100,000 below the 1861 figure; nearly 40,000 of the shrinkage has occurred since 1921.

This depopulation is due partly to the poverty of the region in natural resources but also to political, social and economic handicaps. The Highlanders are extraordinarily poor. Crofting was formerly an adjunct to fishing, which has now in almost every area been killed by the trawlers, with consequent impoverishment not merely through loss of income but also through a change-over to a less satisfactory diet in which tinned and packaged foods figure prominently at higher cost. Deer-stalking has lately suffered a heavy eclipse, and grouse-shooting and fishing, while bringing in a certain amount of income, do little to beriefit the mass of the popula. tion. Except for hydro-electric power development in connexion with the aluminium industry in the Kinlochleven and Fort William area, the natural resources of the area have not proved suitable for exploitation. 
A high proportion of the occupied population is notoriously poorly paid, and the age structure of the population is becoming increasingly unsatisfactory, the proportion of persons in the age groups up to forty-five years being lower than for Scotland as a whole, especially in the groups below thirty years, while in the age-groups sixty-five-eighty years it is more than fifty per cent above the average. The marriage rate is well below the Scottish average, but the mobility of the population is greater than is often supposed. Transport charges are a serious obstacle to development, and ferry and other tolls are notorious.

The greatest possibilities of development lie in tourist traffic. More and better-run hotels, improved train and bus services, the encouragement of walkers as well as road touring, and maintenance of more adequate information and propaganda services should assist to attract the necessary money from outside. The tourist industry would also stimulate such other industries as sea-fishing, the cultivation of fruit and vegetables, and local handicrafts. Afforestation linked up with timber-processing, quarrying and wool are other possibilities, all of which demand leadership. Orthodox methods are inapplicable to Highland conditions, and the establishment of a form of Development Board through Parliament may be ultimately required.

\section{Educational Topics and Events}

Aberdeen.-During the interregnum between the departure of Prof. James Ritchie to the University of Edinburgh and the arrival of a successor, the University Court has appointed Prof. Walter Garstang, formerly of the University of Leeds, to take charge of the Natural History Department in Aberdeen.

Canibridge.-The Managers of the Balfour Fund have made the following grants : to W. GrahamSmith, of Gonville and Caius College, $£ 200$ for an expedition to examine the Devonian fauna of Scaumenac Bay in Canada; to H. E. Hinton, of Fitzwilliam House, $£ 200$ for researches on the biology and distribution of the water-living insects of Lake Titicaca.

At Downing College, Sir Albert Seward, formerly Master of the College, has been elected into an honorary fellowship.

LONDON.-The following appointments have been made : Dr. W. G. Penney, Stokes student at Pembroke College, Cambridge, to be reader in mathematics in the Imperial College-Royal College of Science; Dr. Charles Reid, since 1933 lecturer in physiology at University College, London, to be reader in physiology at the London Hospital Medical College.

The title of professor of applied physical chemistry in the University has been conferred on Mr. G. I. Finch, in respect of the post held by him at the Imperial College-Royal College of Science. The title of emeritus professor of statistics in the University has been conferred on Prof. A. L. Bowley, on his retirement from the University chair of statistics at the London School of Economics.
The following awards have been made: George Smith studentship to T. J. B. Spencer (King's College); Graham scholarship in pathology to C. H. Gray; Loch exhibitions to Miss A. C. Anderson and Mrs. E. M. Pegram (London School of Economics); Metcalfe scholarship for women to Miss V. M. Rossitter; proxime accessit, Miss Adasia Steinberg; Metcalfe studentship for women to Miss G. H. Keir ; Rogers prize to Dr. R. P. Kemp.

Dr. S. J. Davies, who has been University reader in mechanical engineering at King's College since 1926, has been appointed, as from January 1, 1937, to the University chair of mechanical engineering tenable at King's College.

Manchester.-Prof. J. L. Stocks will vacate the Sir Samuel Hall chair of philosophy at the end of this term consequent on his appointment as vicechancellor of the University of Liverpool.

The following resignations take effect from the beginning of the session: Dr. T. A. Bennet-Clark (lecturer in botany, appointed professor of botany at University College, Nottingham); Messrs. Frank Morton and L. W. Derry (demonstrators in applied chemistry in the Faculty of Technology).

The following appointments have been made as from the beginning of the session: Mr. A. C. Lovell, to be assistant lecturer in physics; Dr. R. F. Hunter, to be assistant lecturer in chemistry; Dr. V. J. Chapman, to be assistant lecturer in botany.

The Metallurgical Department has received a research grant from the International Tin Research and Development Council.

Oxford.--Prof. A. R. Radcliffe-Brown has been appointed to the newly created chair of social anthropology as from January 1, 1937.

Prof. Frederick Soddy has intimated his desire to resign the Dr. Lee's professorship of inorganic and physical chemistry to which he was appointed in 1919 .

In Convocation on October 27 the honorary degree of D.C.L. was conferred on President J. B. Conant, of Harvard University.

Congregation on October 20 accepted by 68 votes to 32 a scheme for altering the traditional rotation for the appointment of the vice-chancellor and giving the Chancellor wide powers of discretion. The aims of the scheme are to get younger men and longer term in office. Some of the promoters of it would have welcomed a permanent vice-chancellorship. Others, while preferring the present temporary appointment, would like to have it thrown open to any member of Congregation. The present feeling, however, is against these radical changes and in favour, merely, of making eligible for office any head of a college independent of his seniority. It is commonly agreed that the present vice-chancellor-the Master of Balliol--who happens to be one of the younger heads of a college, is the most successful one of recent years.

The numbers of those who took research degrees at Oxford in the past academic year have recently been published. They serve to show the main groups of subjects in which research is being carried out. They are-physical sciences : 45 B.Sc., 17 D.Phil.; biological sciences, 6 B.Sc., 6 D.Phil.; medicine, 2 B.Sc., 2 D.Phil. ; social studies, 5 B.Litt., 4 D.Phil.; modern history, 12 B.Litt., 6 D.Phil.; all other subjects : 23 B.Litt., 4 D.Phil. Thirty-eight of the forty-five bachelors in the physical sciences are chemists. 